\title{
Analisis Faktor Dan Kebiasaan Melakukan Pengobatan Tradisional Dengan Keluhan Muskuloskeletal Pada Pekerja Tenun di Desa Kembang Kerang Daya, Kabupaten Lombok Timur
}

\section{Analysis Factor And Habit Of Doing Traditional Medicine With Musculoskeletal Complaint In Weaving Workers in The Kembang Kerang Daya Village, East Lombok District}

\begin{abstract}
Muhamad Majdi ${ }^{1}$, Ahmad Ruhardi ${ }^{2}$
$[1,2]^{*}$ Program Studi Kesehatan Lingkungan, Sekolah Tinggi Teknik Lingkungan Mataram

e-mail: muhamadmajdi89@gmail.com

Abstrak

Berdasarkan World Health Organization (WHO) bahwa risiko pekerjaan penyebab kesakitan dan kematian berada ditingkat kesepuluh, faktor risiko secara global untuk jumlah kesakitan dan kematian yaitu 37\% back pain, 16\% hearing loss, 13\% chronic obstructive lung disease, 11\% asma, 10\% cedera, 9\% kanker paru, dan 2\% leukimia. Pada profil kesehatan di Indonesia tahun 2008, jumlah penderita muskuloskeletal di Rumah Sakit di Indonesia sebesar 175.132 kunjungan (29,8\%). Hasil studi pendahuluan yang telah dilakukan, diperoleh masalah terkait keluhan muskuloskeletal pada pekerja tenun di Desa Kembang Kerang Daya meliputi: tangan, bahu, pinggang, dan pantat terasa nyeri dan pegal karena melakukan pergerakan tubuh dalam waktu yang lama. Tujuan dari penelitian ini adalah menganalisis faktor penyebab keluhan muskuloskeletal pada pekerja tenun dengan menyajikan data yang telah diukur dengan metode Ovako Working Analysis System dan kuesioner Nordic Body Map yang juga disajikan dalam bentuk tabel dan distribusi frekuensi. Metode yang digunakan dalam penelitian ini adalah observasional analitik dengan rancangan cross sectional. Penelitian ini dilaksanakan pada pekerja tenun di Desa Kembang Kerang Daya, Kabupaten Lombok Timur dengan sampel penelitian berjumlah 68 orang. Data yang diperoleh dari hasil penelitian akan dianalisis secara deskriptif dan statistik meliputi analisis univariate, bivariate, dan multivariate. Hasil uji statistik dengan chi square bahwa faktor sikap kerja $(p=0,000$ dan OR= 23,754), umur ( $p=0,019$ dan OR= 5,517), dan kebiasaan melakukan pengobatan tradisional $(p=0,001$ dan OR= 10,855) memiliki hubungan yang signifikan dengan keluhan muskuloskeletal dengan nilai signifikan $(\alpha<0,05)$. Hasil analisis multivariat menunjukkan bahwa terdapat 2 variabel independen yang memiliki hubungan signifikan dengan keluhan muskuloskeletal, yaitu sikap kerja ( $p=$ $0,002)$, dan kebiasaan melakukan pengobatan tradisional $(p=0,049)$. Sedangkan variabel umur tidak memiliki hubungan dengan keluhan muskuloskeletal $(p=0,102)$. Kesimpulan dalam penelitian ini adalah faktor risiko yang paling dominan mempengaruhi keluhan muskuloskeletal adalah sikap kerja dengan nilai odds ratio (OR) sebesar 23,754.
\end{abstract}

Kata kunci: Ovako Working Analysis System, Nordic Body Map, Keluhan Muskuloskeletal.

\section{Abstract}

Based on the World Health Organization (WHO) that the risk of occupational causes of illness and death is at the tenth level, global risk factors for the amount of morbidity and death are $37 \%$ back pain, $16 \%$ hearing loss, $13 \%$ chronic obstructive lung disease, $11 \%$ asthma, $10 \%$ of injury, $9 \%$ of lung cancer, and $2 \%$ of leukemia.On the health profile in Indonesia in 2008 , the number of musculoskeletal sufferers in hospitals in Indonesia was 175,132 visits $(29.8 \%)$. While the results of a preliminary study obtained problems related to musculoskeletal complaints in weaving workers in the Kembang Kerang Daya Village including: hands, shoulders, hips, and buttocks aching and aching due to body movements for a long time. The purpose of this study is to determine the causes of musculoskeletal complaints in weaving workers by presenting data that has been measured by the Ovako Working Analysis System method and Nordic Body Map which is also presented in tabular and frequency distribution. The method used in this study was observational analytic with cross sectional design. The research will be carried out on weaving workers in the Kembang Kerang Daya Village, East Lombok Regency with a sample of 68 people. Data obtained from the results of the study will be analyzed descriptively and statistically including univariate analysis, bivariate, and multivariate. According to the results of statistical tests with chi square that work attitude $(p=0,000$ and $O R=23,754)$, age $(p=0,019$ and $O R=5,517)$, and the habit of doing traditional medicine $(p=0,001$ and $O R=10,855)$ is a significant relationship between treatment with musculoskeletal complaints. Multivariate analysis showed that there are two independent variables that have a significant relationship with musculoskeletal complaint with $(a<0,05)$, the work attitude $(p=0,002)$, and the habit of doing traditional medicine $(p=$ $0,049)$. While the age variable $(p=0,102)$ had no relationship with musculoskeletal complaints. The conclusion in this study, it is known that the most dominant risk factor affecting musculoskeletal complaints is work attitude with an odds ratio (OR) of 23.754 .

Keywords: Ovako Working Analysis System, Nordic Body Map, Muskuloskeletal Complaints.

Doi: https://doi.org/10.31943/afiasi.v5i1.91 


\section{Pendahuluan}

Semua industri sektor usaha formal dan informal diharapkan dapat menerapkan keselamatan dan kesehatan kerja (K3) dalam menjalankan tugas agar para pekerja merasa aman dalam bekerja dan bebas dari penyakit akibat kerja. Salah satu penyakit akibat kerja adalah keluhan muskuloskeletal disorders (MSDs). MSDs merupakan gangguan fungsi normal otot, tendon, saraf, pembuluh darah, tulang, ligamen akibat perubahan struktur atau sistem muskuloskeletal dalam waktu pendek ataupun lama ${ }^{1}$.

Berdasarkan pada profil kesehatan di Indonesia tahun 2008, jumlah penderita keluhan muskuloskeletal disorders pada rumah sakit di Indonesia sebesar 175.132 kunjungan $(29,8 \%)^{2}$. Penyebab keluhan muskuloskeletal yaitu peregangan otot yang berlebihan, aktivitas berulang, dan sikap kerja tidak alamiah. Adapun faktor risiko terhadap keluhan muskuloskeletal diantaranya faktor individu (umur, jenis kelamin, masa kerja, kebiasaan merokok, kebiasaan olahraga, dan indeks masa tubuh), faktor pekerjaan (postur kerja, berat badan, durasi, pengulangan atau frekuensi), dan faktor lingkungan (paparan suhu, dan getaran) ${ }^{3}$.

Berdasarkan hasil riset oleh International Labour Organization (ILO), menyatakan bahwa setiap hari rata-rata 6.000 orang meninggal dunia, setara dengan satu orang setiap 15 detik atau 2,2 juta orang per tahun akibat sakit atau kecelakaan yang berkaitan dengan pekerjaan mereka. Sekitar 300.000 kematian terjadi dari 250 juta kecelakaan dan sisanya adalah kematian karena penyakit akibat hubungan pekerjaannya, dimana diperkirakan terjadi 160 juta penyakit akibat hubungan pekerjaan baru setiap tahunnya ${ }^{4}$.Sedangkan World Health Organization (WHO) menyatakan bahwa risiko pekerjaan penyebab kesakitan dan kematian berada ditingkat kesepuluh, faktor risiko secara global untuk jumlah kesakitan dan kematian yaitu $37 \%$ back pain, $16 \%$ hearing loss, $13 \%$ chronic obstructive lung disease, $11 \%$ asma, $10 \%$ cedera, $9 \%$ kanker paru, dan $2 \%$ leukimia ${ }^{5}$.

Berdasarkan hasil studi pendahuluan yang telah dilakukan pada pekerja tenun di Desa Kembang Kerang Daya, dari beberapa pekerja tenun yang diwawancarai terkait dengan keluhan muskuloskeletal didapat bahwa pekerja mengeluhkan adanya keluhan rasa nyeri dan pegal-pegal pada tangan, bahu, pinggang, pantat, paha kiri, paha kanan, betis, dan kaki kiri. Sedangkan ketika bekerja, pekerja tenun biasanya melakukan pergerakan tubuh dalam waktu yang lama, postur tubuh dalam bekerja tidak ergonomis, tidak adanya jeda istirahat ketika bekerja dan terlalu dipaksakan, serta duduk atau berdiri terus menerus dalam durasi yang lama. Pekerja tenun di Desa Kembang Daya juga memiliki jenis kelamin dan umur yang berbeda-beda, sehingga akan mempengaruhi perbedaan tingkat keluhan yang dialami oleh pekerja.

Apabila kondisi tersebut di atas terus berlangsung dan tidak ada pengendalian, maka akan memicu permasalahan baru seperti kehilangan waktu bekerja akibat cedera dan akan ada penurunan produktivitas pekerja. Adapun tujuan dari penelitian ini adalah menganalisis faktor penyebab keluhan muskuloskeletal pada pekerja tenun di Desa Kembang Kerang Daya, Kabupaten Lombok Timur. Sedangkan manfaat dari penelitian ini supaya dapat memberikan informasi ilmiah dalam perkembangan ilmu kesehatan dan keselamatan kerja terutama tentang penyebab keluhan muskuloskeletal serta sebagai sumber refrensi dalam peningkatan penelitian di perguruan tinggi. 


\section{Metode Penelitian}

Jenis penelitian yang digunakan dalam penelitian ini adalah observasional analitik ${ }^{6}$. Rancangan penelitian yang digunakan adalah cross sectional ${ }^{7}$. Penelitian ini dilakukan pada pekerja tenun di Desa Kembang Kerang Daya, Kabupaten Lombok Timur. Teknik pengambilan sampel yang digunakan adalah quota sampling, dengan kriteria inklusi responden bekerja hanya sebagai pekerja tenun di Desa Kembang Kerang Daya. Sedangkan kriteria ekslusi responden tidak bersedia dijadikan sampel penelitian. Berdasarkan kriteria tersebut didapat jumlah sampelnya 68 orang. Data dikumpulkan dengan kuesioner Nordic Body Map yang digunakan sebagai alat ukur keluhan muskuloskeletal, kuesioner identitas responden berupa daftar isian yang berisi data nama responden, umur, dan kebiasaan melakukan pengobatan tradisional, dan lembar kerja penilaian Ovako Working Analysis System untuk mengukur sikap kerja, dan kamera digital untuk pengambilan gambar sebagai data pendukung. Analisis data yang digunakan adalah analisis univariate, analisis bivariate dengan uji chi square, dan analisis multivariat dengan uji regresi logistik.

\section{Hasil}

Berikut distribusi keluhan muskuloskeletal pada pekerja tenun di Desa Kembang Kerang Daya berdasarkan bagian tubuh dapat dilihat pada tabel 1 berikut :

Tabel 1. Distribusi keluhan muskuloskeletal berdasarkan bagian tubuh

\begin{tabular}{llll}
\hline No & Keluhan bagian tubuh & (n) & \% \\
\hline 1 & Nyeri di leher atas & 13 & 7,18 \\
2 & Nyeri di bahu kiri & 10 & 5,52 \\
3 & Nyeri di lengan atas kiri & 7 & 3,86 \\
4 & Nyeri di lengan atas kanan & 5 & 2,76 \\
5 & Nyeri di pinggul & 9 & 5,00 \\
6 & Nyeri di siku kiri & 3 & 1,66 \\
7 & Nyeri di lengan bawah kiri & 5 & 2,76 \\
8 & Nyeri di pergelangan tangan kiri & 6 & 3,32 \\
9 & Nyeri di tangan kiri & 5 & 2,76 \\
10 & Nyeri di paha kiri & 4 & 2,21 \\
11 & Nyeri di lutut kiri & 3 & 1,66 \\
12 & Nyeri di betis kiri & 9 & 5,00 \\
13 & Nyeri di pergelangan kaki kiri & 2 & 1,10 \\
14 & Nyeri di kaki kiri & 3 & 1,66 \\
15 & Nyeri di tengkuk & 2 & 1,10 \\
16 & Nyeri di bahu kanan & 18 & 9,94 \\
17 & Nyeri di punggung & 10 & 5,52 \\
18 & Nyeri di pinggang & 16 & 8,84 \\
19 & Nyeri di pantat & 5 & 2,76 \\
20 & Nyeri di siku kanan & 2 & 1,10 \\
21 & Nyeri di lengan bawah kanan & 5 & 2,76 \\
22 & Nyeri di pergelangan tangan kanan & 7 & 3,86 \\
23 & Nyeri di tangan kanan & 5 & 2,76 \\
24 & Nyeri di paha kanan & 5 & 2,76 \\
25 & Nyeri di lutut kanan & 4 & 2,21 \\
26 & Nyeri di betis kanan & 7 & 3,86 \\
27 & Nyeri di pergelangan kaki kanan & 6 & 3,32 \\
28 & Nyeri di kaki kanan & 5 & 2,76 \\
& & 181 & $100 \%$ \\
\hline & Keterangan: & & \\
\hline
\end{tabular}

Keterangan: $\mathrm{n}=$ Jumlah, $\%=$ Persentase 
Berdasarkan tabel 1 di atas dapat diketahui bahwa keluhan muskuloskeletal berdasarkan bagian tubuh terbanyak dirasakan pekerja pada bagian bahu kanan sebanyak 18 orang $(9,94 \%)$, pinggang sebanyak 16 orang $(8,84 \%)$, dan leher atas sebanyak 13 orang $(7,18 \%)$.

Hasil analisis univariat dibedakan menurut variabel bebas seperti sikap kerja, umur, dan kebiasaan melakukan pengobatan tradisional, dan variabel terikat seperti keluhan muskuloskeletal. Hasil analisisnya dapat dilihat pada tabel 2 berikut :

Tabel 2. Hasil analisis uji univariat

\begin{tabular}{llll}
\hline Variabel & Kategori & $\mathbf{n}$ & $\mathbf{\%}$ \\
\hline Sikap Kerja & Tidak perbaikan & 15 & 22,10 \\
& Perbaikan & 53 & 77,90 \\
& Total & $\mathbf{6 8}$ & $\mathbf{1 0 0}$ \\
Umur & Muda $(<40$ tahun) & 42 & 61,80 \\
& Tua $(\geq 40$ tahun) & 26 & 38,20 \\
& Total & $\mathbf{6 8}$ & $\mathbf{1 0 0}$ \\
Kebiasaan & Tidak rutin $(\leq 1$ kali) & 35 & 51,50 \\
Melakukan & Rutin $(>1$ kali) & 33 & 48,50 \\
Pengobatan & Total & $\mathbf{6 8}$ & $\mathbf{1 0 0}$ \\
Tradisional & & & \\
(kali/minggu) & & & \\
Keluhan & Rendah & 12 & 17,60 \\
Muskuloskeletal & Sedang & 56 & 82,40 \\
& Total & $\mathbf{6 8}$ & $\mathbf{1 0 0}$ \\
\hline
\end{tabular}

Keterangan: $\mathrm{n}=$ Jumlah, $\%=$ Persentase

Berdasarkan tabel 2 menunjukkan bahwa jumlah pekerja dengan sikap kerja yang perlu dilakukan perbaikan berjumlah 53 orang $(77,90 \%)$, sedangkan pekerja dengan sikap kerja yang tidak perlu dilakukan perbaikan berjumlah 15 orang $(22,10 \%)$. Jumlah pekerja dengan umur $\geq 40$ tahun (Tua) berjumlah 26 orang $(38,20 \%)$, sedangkan pekerja tenun dengan umur $<40$ tahun (Muda) hanya berjumlah 42 orang $(20,97 \%)$. Jumlah pekerja tenun dengan kebiasaan melakukan pengobatan tradisional yang tidak rutin $(\leq 1$ kali) berjumlah 35 orang $(51,50 \%)$, sedangkan pekerja tenun dengan kebiasaan melakukan pengobatan tradisional yang rutin ( $>1 \mathrm{kali}$ ) berjumlah 33 orang $(48,50 \%)$. Jumlah pekerja tenun dengan keluhan muskuloskeletal sedang yaitu berjumlah 56 orang $(82,40 \%)$, sedangkan pekerja tenun dengan keluhan muskuloskeletal rendah berjumlah 12 orang $(17,60 \%)$. 
Hasil analisis uji bivariat disajikan pada tabel 3 berikut :

Tabel 3. Hasil analisis uji bivariat

\begin{tabular}{|c|c|c|c|c|c|c|}
\hline \multirow[t]{3}{*}{ Variabel } & \multicolumn{4}{|c|}{$\begin{array}{c}\text { Keluhan } \\
\text { Muskuloskeletal }\end{array}$} & \multirow[t]{3}{*}{ OR } & \multirow[t]{3}{*}{$p$} \\
\hline & \multicolumn{2}{|c|}{ Rendah } & \multicolumn{2}{|c|}{ Sedang } & & \\
\hline & $\mathbf{n}$ & $\%$ & $\mathbf{n}$ & $\%$ & & \\
\hline \multicolumn{7}{|l|}{ Sikap Kerja } \\
\hline Tidak perbaikan & 9 & 2,6 & 6 & 12,4 & 23,754 & 0,000 \\
\hline Perbaikan & 3 & 9,4 & 50 & 43,6 & & \\
\hline \multicolumn{7}{|l|}{ Umur } \\
\hline Muda (<40 tahun) & 11 & 7,4 & 31 & 34,6 & 5,517 & 0,019 \\
\hline Tua $(\geq 40$ tahun $)$ & 1 & 4,6 & 25 & 21,4 & & \\
\hline \multicolumn{7}{|c|}{$\begin{array}{l}\text { Kebiasaan Melakukan } \\
\text { Pengobatan Tradisional } \\
\text { (kali/minggu) }\end{array}$} \\
\hline Rutin (> 1 kali) & 11 & 5,8 & 22 & 27,2 & 10,855 & 0,001 \\
\hline Tidak rutin $(\leq 1$ kali $)$ & 1 & 6,2 & 34 & 28,8 & & \\
\hline
\end{tabular}

Keterangan: $\mathrm{n}=$ Jumlah, $\%=$ Persentase, $\mathrm{OR}=$ Odds Ratio, $\mathrm{p}=$ Probability

Berdasarkan tabel 3 menunjukkan bahwa keluhan muskuloskeletal kategori sedang lebih banyak terjadi pada pekerja tenun dengan sikap kerja perlu perbaikan sebanyak 50 orang (43,6\%), dan untuk keluhan muskuloskeletal kategori ringan lebih banyak terjadi pada pekerja tenun dengan sikap kerja tidak perlu perbaikan sebanyak 9 orang $(2,6 \%)$. Berdasarkan hasil analisis bivariat dengan uji chi square antara sikap kerja dengan keluhan muskuloskeletal diperoleh nilai probability $(p)=0,000$ dengan taraf signifikan $(\alpha<0,05)$ sehingga dapat disimpulkan bahwa ada hubungan antara sikap kerja dengan keluhan muskuloskeletal.

Hasil analisis tabel 3 menunjukkan bahwa keluhan muskuloskeletal kategori sedang lebih banyak terjadi pada pekerja tenun dengan umur $<40$ tahun (Muda) sebanyak 31 orang $(34,6 \%)$, dan untuk keluhan muskuloskeletal kategori ringan lebih banyak terjadi pada pekerja tenun dengan umur $<40$ tahun (Muda) sebanyak 11 orang $(7,4 \%)$. Berdasarkan hasil analisis bivariat dengan uji chi square antara umur dengan keluhan muskuloskeletal diperoleh nilai probability $(\mathrm{p})=0,019$ dengan taraf signifikan $(\alpha<0,05)$, sehingga dapat disimpulkan bahwa ada hubungan antara umur dengan keluhan muskuloskeletal.

Hasil analisis tabel 3 menunjukkan bahwa keluhan muskuloskeletal kategori sedang lebih banyak terjadi pada pekerja tenun dengan kebiasaan melakukan pengobatan tradisional tidak rutin ( $\leq 1$ kali) sebanyak 34 orang $(28,8 \%)$, sedangkan untuk keluhan muskuloskeletal kategori ringan lebih banyak terjadi pada pekerja tenun dengan kebiasaan melakukan pengobatan tradisional rutin (> 1 kali) sebanyak 11 orang $(5,8 \%)$. Berdasarkan hasil analisis bivariat dengan uji chi square antara kebiasaan melakukan pengobatan tradisional dengan keluhan muskuloskeletal diperoleh nilai probability $(\mathrm{p})=0,001$ dengan taraf signifikan $(\alpha<0,05)$ sehingga dapat disimpulkan bahwa ada hubungan antara kebiasaan melakukan pengobatan tradisional dengan keluhan muskuloskeletal. 
Hasil dari analisis multivariat disajikan pada tabel 4 berikut :

Tabel 4. Hasil analisis uji multivariate

\begin{tabular}{ccc}
\hline Variabel & OR & $\boldsymbol{P}$ \\
\hline Sikap kerja & 23,754 & 0,002 \\
Umur & 5,517 & 0,102 \\
Kebiasaan Melakukan & 10.855 & 0,049 \\
Pengobatan Tradisional & & \\
\hline \multicolumn{2}{l}{ Keterangan: $\mathrm{p}=$ Probability, OR= Odds Ratio }
\end{tabular}

Berdasarkan tabel 4 di atas, hasil analisis multivariate menunjukkan bahwa terdapat 2 variabel independen yang memiliki hubungan signifikan dengan keluhan muskuloskeletal $(\mathrm{p}<0,05)$, yaitu sikap kerja $(\mathrm{p}=0,002)$, dan kebiasaan melakukan pengobatan tradisional $(\mathrm{p}=0,049)$. Sedangkan variabel umur tidak berpengaruh signifikan terhadap keluhan muskuloskeletal $(p=0,102)$. Tabel 4 menunjukkan bahwa faktor risiko yang paling dominan mempengaruhi keluhan muskuloskeletal adalah sikap kerja dengan nilai odds ratio (OR) sebesar 23,754 yang artinya peluang pekerja tenun mengalami keluhan muskuloskeletal akibat sikap kerja sebesar 23,754 kali.

\section{Pembahasan}

\section{Gambaran Subjektif Keluhan Muskuloskeletal Pada Pekerja Tenun Di Desa Kembang Kerang Daya}

Berdasarkan tabel 2 diketahui bahwa sebanyak 56 orang pekerja mengalami keluhan muskuloskeletal risiko sedang, dan 12 pekerja mengalami risiko rendah. hal ini dapat diartikan bahwa 82,40\% pekerja mengalami keluhan muskuloskeletal pada pekerja tenun di Desa Kembang Kerang Daya. Pada tabel 1 distribusi keluhan muskuloskeletal terbesar dirasakan oleh pekerja pada bagian bahu kanan, pinggang, leher atas, bahu kiri, punggung, pinggul, dan betis kiri. Keluhan tersebut dapat diakibatkan oleh proses kerja pada saat menenun. Proses kerja menenun terdiri dari proses pembuatan motif pada benang dan pembuatan kain. Proses pembuatan motif pada benang yaitu moyon, merane, menggambar, mengikat, menyelup, melepas ikatan, dan pemisahan benang. Proses kerja saat pembuatan motif pada benang mengharuskan pekerja berdiri atau duduk monoton, tangan kiri terangkat naik turun, tangan kanan memutar, dan kepala bergerak untuk memantau. Sedangkan proses kerja saat pembuatan kain mengharuskan pekerja duduk monoton dengan posisi kaki membuka atau merapat, tangan kiri dan kanan bergerak untuk pengaturan motif kain, dan kepala menunduk dengan pergerakan memantau. 
Berikut adalah beberapa contoh gambar posisi kerja pada pekerja tenun yang dapat menyebabkan sakit, nyeri, dan pegal-pegal pada bagian anggota tubuh :
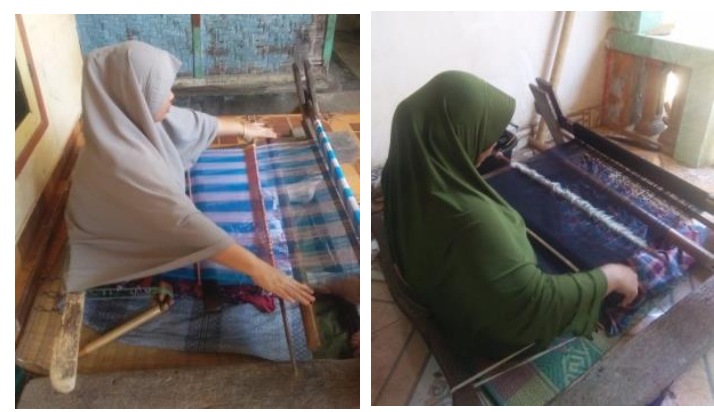

Gambar 1. Contoh posisi kerja yang dapat menyebabkan sakit pada bagian bahu, pinggang, lengan, dan pantat.
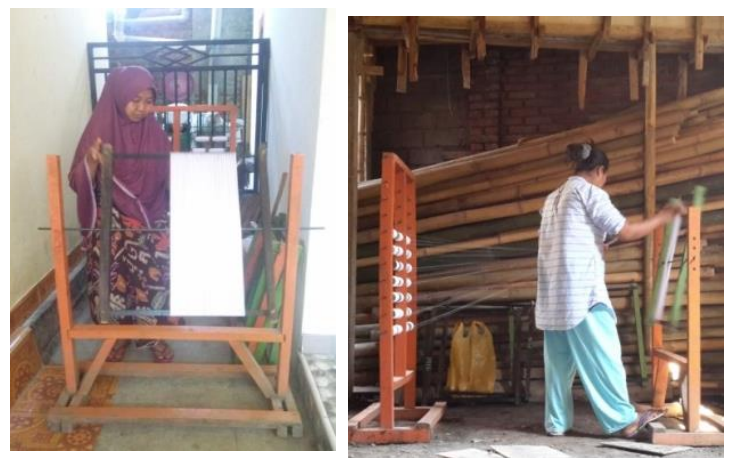

Gambar 2. Contoh posisi kerja yang dapat menyebabkan sakit pada bagian leher, tangan, paha, dan kaki.

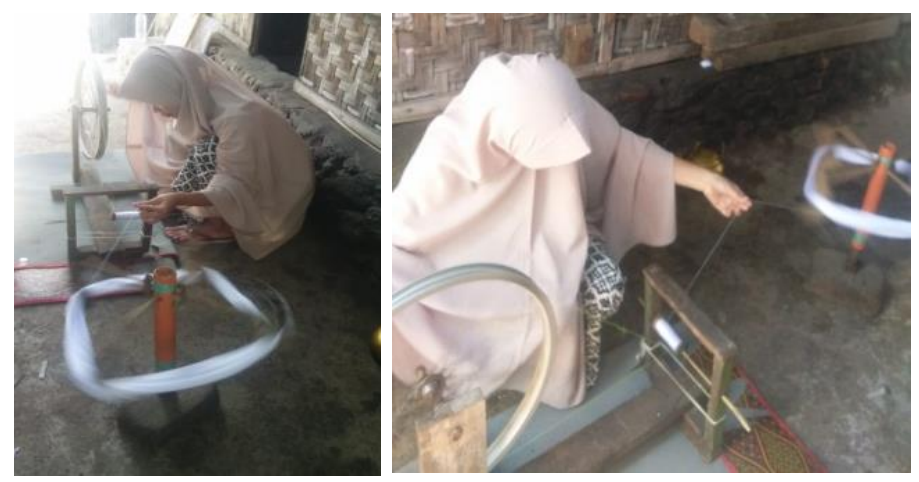

Gambar 3. Contoh posisi kerja yang dapat menyebabkan sakit pada bagian punggung, bahu, pinggang, lutut, dan betis.

Proses duduk monoton yang dilakukan terus menerus akan berisiko mengakibatkan keluhan nyeri pada beberapa bagian tubuh seperti pinggang, pinggul, pantat, dan akan menyebar kebagian kaki. Proses mengangkat, menurunkan, dan memutar tangan dengan proses kerja tidak dilakukan secara ergonomis akan mengakibatkan ketegangan pada bagian lengan bagian atas. Belum lagi proses tersebut dilakukan dengan posisi duduk dengan sikap punggung condong ke depan sehingga dapat menyebabkan keluhan pada bagian bahu, punggung, dan pinggang. 
Selain sikap kerja dengan duduk, pekerja tenun juga beberapa bekerja dengan posisi berdiri. Posisi berdiri saat bekerja cukup berisiko untuk menyebabkan keluhan nyeri pada beberapa bagian tubuh seperti bahu, lutut, dan betis. Posisi berdiri dengan badan bagian atas membungkuk, tangan kiri terangkat, dan tangan kanan naik turun juga merupakan sikap yang berisiko untuk terjadinya keluhan pada tubuh. Posisi kerja berdiri dan agak sedikit membungkuk dalam waktu yang lama juga akan menyebabkan rasa nyeri pada bagian leher, punggung, pinggang, dan paha.

Postur tidak alamiah dapat menyebabkan otot tidak dapat bekerja efisien, oleh karena itu otot memerlukan kekuatan lebih untuk dapat menyelesaikan tugasnya, hal ini dapat meningkatkan beban yang dapat menyebabkan kelelahan dan ketegangan pada otot dan tendon. Sedangkan gerakan yang terlalu sering, cepat dan dalam waktu yang lama dapat menyebabkan keluhan otot karena otot menerima tekanan akibat beban kerja terus menerus tanpa melakukan relaksasi ${ }^{7}$.

Penelitian ini sejalan dengan penelitian yang telah dilakukan oleh Mutiah, dkk pada pekerja pembuat wajan, yang menyatakan bahwa bagian tubuh yang memiliki risiko MSDs adalah bagian punggung sebanyak 33 orang (75\%), dan tangan kanan sebanyak 21 orang $(47,7 \%)^{9}$.

\section{Hubungan Sikap Kerja dengan Keluhan Muskuloskeletal Pada Pekerja Tenun Di Desa Kembang Kerang Daya.}

Penilaian sikap kerja pada pekerja tenun di Desa Kembang Kerang Daya dianalisis menggunakan lembar kerja metode $O W A S$ dengan unsur penilaian sikap atau postur seperti punggung, lengan, kaki, beban kerja, dan fase kerja. Metode $O W A S$ memberikan informasi penilaian postur tubuh pada saat bekerja sehingga dapat melakukan evaluasi dini atas resiko kecelakaan tubuh manusia. Berdasarkan hasil analisis univariat pada tabel 2 menunjukkan bahwa jumlah pekerja dengan sikap kerja perlu dilakukan perbaikan berjumlah sebanyak 53 orang $(77,90 \%)$, dan sikap kerja tidak perbaikan berjumlah sebanyak 15 orang $(22,10 \%)$. Hasil analisis bivariat pada tabel 3 menunjukkan bahwa responden yang sikap kerja perlu perbaikan lebih banyak mengalami keluhan muskuloskeletal tingkat sedang sebanyak 50 orang $(43,60 \%)$ sedangkan responden dengan sikap kerja tidak perlu perbaikan lebih banyak mengalami keluhan muskuloskeletal tingkat rendah sebanyak 9 orang $(2,60 \%)$. Nilai $\mathrm{p}=0,000$ menunjukkan bahwa hipotesis penelitian diterima, artinya terdapat hubungan yang signifikan antara sikap kerja dengan keluhan muskuloskeletal. Hasil perhitungan $\mathrm{OR}=23,754$ menunjukkan bahwa responden dengan sikap kerja perlu parbaikan memiliki peluang mengalami keluhan muskuloskeletal sebesar 23,754 kali dibandingkan dengan responden dengan sikap kerja tidak perlu dilakukan perbaikan. Semakin tinggi tingkat risiko yang ditunjukkan melalui sikap kerja maka semakin besar pula keluhan muskuloskeletal. Hasil analisis ini diperkuat dengan hasil analisis multivariat dengan regresi logistik menunjukkan adanya hubungan secara statistik antara postur kerja dengan keluhan muskuloskeletal dengan nilai $\mathrm{p}=0,002$.

Hasil penilaian sikap kerja responden pada pekerja tenun di Desa Kembang Kerang Daya dengan menggunakan metode $O W A S$ diperoleh hasil bahwa seluruh pekerjaan dilakukan dengan sikap kerja yang tidak alamiah, dengan tingkat risiko ergonomi tidak perlu perbaikan dan perlu dilakukan perbaikan. Skor $O W A S$ terendah adalah 1, yaitu pada saat bekerja sikap kerja punggung tegak, kedua tangan berada di atas level ketinggian bahu, kaki dalam posisi duduk, dan berat beban kurang dari $10 \mathrm{~kg}$. Skor $O W A S$ tertinggi adalah 2, yaitu pada saat bekerja punggung membungkuk, satu tangan berada di atas level ketinggian bahu, kaki dalam posisi duduk, dan berat beban kurang dari $10 \mathrm{~kg}$.

Hasil penelitian ini sejalan dengan penelitian yang menyatakan bahwa posisi kerja yang berisiko akan meningkatkan keluhan $M S D$ s pada pekerja batik, dengan nilai $\mathrm{p}=0,000^{10}$. Penelitian 
yang lain juga menyatakan bahwa ada hubungan yang signifikan antara postur kerja dengan keluhan muskuloskeletal disorders pada pekerja beton sektor informal di Kelurahan Semata Kecamatan Somba Opu Kabupaten Gowa dengan nilai $\mathrm{p}=0,000^{11}$.

\section{Hubungan Umur Dengan Keluhan Muskuloskeletal Pada Pekerja Tenun Di Desa Kembang Kerang Daya.}

Dari hasil analisis uji univariat memperlihatkan bahwa pekerja tenun dengan umur muda (< 40 tahun) berjumlah 42 orang dan pekerja tenun dengan umur tua ( $\geq 40$ tahun) berjumlah 26 orang. Hasil analisis bivariat pada tabel 6 dapat dilihat bahwa keluhan muskuloskeletal dengan tingkat sedang dijumpai pada pekerja dengan umur muda sebanyak 31 orang $(34,60 \%)$ dan pekerja dengan umur tua sebanyak 25 orang $(21,40 \%)$. Sementara untuk keluhan muskuloskeletal dengan tingkat rendah dijumpai pada pekerja dengan umur muda sebanyak 11 orang $(7,40 \%)$ dan pekerja dengan umur tua sebanyak 1 orang $(4,60 \%)$. Berdasarkan uji statistik disimpulkan bahwa umur menunjukkan nilai probability $(\mathrm{p})=0,019$ dan nilai odds ratio $(\mathrm{OR})=5,517$. Nilai $\mathrm{p}=0,019$ menunjukkan bahwa hipotesis penelitian diterima, sehingga dapat disimpulkan bahwa ada hubungan yang signifikan antara umur dengan keluhan muskuloskeletal.

Signifikannya hubungan antara umur dengan keluhan muskuloskeletal pada pekerja tenun di Desa Kembang Kerang Daya dapat disebabkan karena sebagian besar bekerja dengan tingkat risiko ergonomi. Umur mempunyai hubungan yang erat dengan kekuatan otot, semakin bertambah umur seorang pekerja maka akan semakin rentan mengalami keluhan otot. Pada usia produktif kapasitas kekuatan otot mulai berkurang, sehingga pada usia tersebut memiliki risiko mengalami keluhan muskuloskeletal ${ }^{12}$.

Umur juga memiliki keterkaitan yang erat dengan masa kerja. Semakin bertambahnya usia dibarengi dengan bertambahnya masa kerja seseorang maka akan bertambah juga kejenuhan baik secara fisik maupun psikis. Masa kerja merupakan faktor risiko yang sangat mempengaruhi seorang pekerja untuk meningkatkan risiko terjadinya keluhan muskuloskeletal ${ }^{3}$.

Hasil penelitian ini sejalan dengan penelitian yang hasil penelitiannya menunjukkan bahwa ada hubungan antara umur dengan keluhan muskuloskeletal pada pekerja angkat-angkut industri pemecahan batu dengan nilai $\mathrm{p}=0,001(<0,05)^{13}$. Dan penelitian lainnya juga menyatakan bahwa ada hubungan antara variabel umur dengan keluhan muskuloskeletal pada nelayan dengan nilai $\mathrm{p}=$ $0,049(<0,05)^{14}$.

\section{Hubungan Kebiasaan Melakukan Pengobatan Tradisional Dengan Keluhan Muskuloskeletal Pada Pekerja Tenun Di Desa Kembang Kerang Daya.}

Hasil analisis univariat pada tabel 2 menunjukkan bahwa pekerja tenun di Desa Kembang Kerang Daya dengan kebiasaan melakukan pengobatan tradisional tidak rutin $(\leq 1$ kali) berjumlah sebanyak 35 orang dan kebiasaan melakukan pengobatan tradisional rutin (> 1 kali) berjumlah 33 orang. Dari hasil analisis bivariat pada tabel 6 menunjukkan bahwa keluhan muskuloskeletal dengan tingkat sedang banyak dijumpai pada pekerja dengan kebiasaan melakukan pengobatan tradisional tidak rutin sebanyak 34 orang $(28,80 \%)$. Sementara untuk keluhan muskuloskeletal dengan tingkat rendah terbanyak dijumpai pada pekerja dengan kebiasaan melakukan pengobatan tradisional rutin sebanyak 11 orang $(5,80 \%)$. Berdasarkan uji statistik disimpulkan bahwa kebiasaan melakukan pengobatan tradisional memiliki nilai probability $(\mathrm{p})=0,001$ dan nilai odds ratio $(\mathrm{OR})=$ 10,855. Nilai $\mathrm{p}=0,001$ menunjukkan bahwa hipotesis penelitian diterima, sehingga dapat disimpulkan bahwa ada hubungan yang signifikan antara kebiasaan melakukan pengobatan tradisional dengan keluhan muskuloskeletal. Nilai $\mathrm{OR}=10,855$ menjelaskan bahwa responden 
dengan kebiasaan melakukan pengobatan tradisional tidak rutin memiliki peluang 10,855 kali mengalami keluhan muskuloskeletal dibandingkan responden dengan kebiasaan melakukan pengobatan tradisional rutin.

Signifikannya hubungan antara kebiasaan melakukan pengobatan tradisional dengan keluhan muskuloskeletal pada pekerja tenun di Desa Kembang Kerang Daya dapat disebabkan karena pekerja tenun tidak rutin melakukan pengobatan tradisional saat atau sebelum bekerja. Melakukan pengobatan tradisional yang teraratur dapat mempengaruhi peningkatan kondisi kesehatan. Semakin teratur pengobatan tradisional yang dilakukan pekerja tenun maka akan menurunkan keluhan muskuloskeletal. Bila seseorang kurang melakukan pengobatan tradisional maka akan mudah terkena penyakit yang berakibat pada penurunan stamina.

Menurut World Health Organization (WHO), negara-negara Afrika, Asia, dan Amerika Latin menggunakan pengobatan tradisional sebagai pelengkap pengobatan primer. faktor pendorong terjadinya peningkatan penggunaan pengobatan tradisional adalah usia harapan hidup yang lebih panjang pada saat prevalensi penyakit kronik meningkat. Di Indonesia sendiri, jumlah masyarakat yang memanfaatkan pengobatan tradisional terus meningkat setiap tahunnya. Menurut survei sosial ekonomi tahun 2001, ada sekitar 57,7\% penduduk Indonesia yang melakukan pengobatan sendiri, $31,7 \%$ menggunakan obat tradisional, dan 9,8\% memilih cara pengobatan tradisional. Kemudian pada tahun 2004 jumlah tersebut bertambah secara drastis, tercatat 72,44\% penduduk yang menggunakan pengobatan sendiri dan $32,87 \%$ memilih obat tradisional ${ }^{15}$.

Penelitian ini sejalan dengan penelitian Zegaria yang menyatakan bahwa tujuan dari terapi (salah satu dari pengobatan tradisional) adalah untuk menghilangkan rasa nyeri dan kekakuan, menjaga atau meningkatkan mobilitas sendi, membatasi kerusakan fungsi, dan mengurangi faktor penyebab $^{16}$.

\section{Hubungan Secara Bersama-Sama Antara Sikap Kerja, Umur, Dan Kebiasaan Melakukan Pengobatan Tradisional Dengan Keluhan Muskuloskeletal.}

Hasil penelitian menunjukkan bahwa terdapat hubungan yang signifikan secara bersama-sama antara sikap kerja, umur, dan kebiasaan melakukan pengobatan tradisional dengan keluhan muskuloskeletal pada pekerja tenun di Desa Kembang Kerang Daya. Berdasarkan hasil analisis multivariat bahwa terdapat 2 variabel yang memiliki hubungan yang signifikan dengan keluhan muskuloskeletal yaitu sikap kerja $(\mathrm{p}=0,002)$, dan kebiasaan melakukan pengobatan tradisional $(\mathrm{p}=$ 0,049). Dari hasil analisis multivariat diketahui variabel yang paling dominan mempengaruhi keluhan muskuloskeletal adalah sikap kerja dengan nilai $\mathrm{OR}=23,754$. Variabel umur tidak memiliki hubungan yang signifikan karena pekerja tenun yang paling banyak mengalami keluhan muskuloskeletal kategori sedang adalah usia muda ( $<40$ tahun) berjumlah 31 orang, dan kategori ringan adalah usia muda yang berjumlah 11 orang. Hal ini dimungkinkan karena pekerja tenun di Desa Kembang Kerang Daya paling banyak adalah usia muda ( $<40$ tahun).

Faktor lain yang dianggap mempengaruhi keluhan muskuloskeletal adalah masa kerja, jenis kelamin, kebiasaaan merokok, dll. Menurut penelitian yang menyatakan bahwa terdapat hubungan antara masa kerja dengan keluhan muskuloskeletal pada nelayan di Desa Talikuran Kecamatan Remboken Kabupaten Minahasa dengan nilai $\mathrm{p}=0,000(\alpha<0,05)^{17}$. Dan dalam penelitian lain menyatakan bahwa ada hubungan antara kebiasaan merokok dengan keluhan muskuluskeletal dengan nilai $\mathrm{p}=0,001^{13}$. Sedangkan menurut penelitian lain bahwa ada hubungan yang signifikan antara jenis kelamin dengan keluhan muskuloskeletal dengan $\mathrm{p}=0,010^{10}$. 


\section{Kesimpulan}

Berdasarkan hasil penelitian dan pembahasan bahwa keluhan muskuloskeletal pada pekerja tenun di Desa Kembang Kerang Daya Kabupaten Lombok Timur, menunjukkan bahwa ada hubungan yang signifikan antara sikap kerja $(\mathrm{p}=0,000)$, umur $(\mathrm{p}=0,019)$, dan kebiasaan melakukan pengobatan tradisional $(\mathrm{p}=0,001)$ dengan keluhan muskuloskeletal. Faktor risiko yang paling dominan mempengaruhi keluhan muskuloskeletal adalah sikap kerja $(\mathrm{OR}=23,754)$ yang artinya peluang pekerja tenun mengalami keluhan muskuloskeletal akibat sikap kerja sebesar 23,754 kali.

\section{Saran}

Berdasarkan hasil penelitian, pembahasan, dan kesimpulan disarankan kepada pekerja tenun, bahwa perlu adanya pendidikan dan pelatihan dalam hal ergonomi untuk meningkatkan pemahaman kepada pekerja agar tidak mengalami keluhan muskuloskeletal. Pekerja yang sudah mengalami keluhan muskuloskeletal disarankan secara mandiri dan rutin melakukan pengobatan.

\section{Ucapan TerimaKasih}

Penulis mengucapkan terima kasih kepada semua pihak terkait antara lain, Direktorat Riset dan Pengabdian Masyarakat (DRPM) yang telah memberikan dana hibah penelitian dosen pemula (PDP) pendanaan Tahun 2019. Penulis juga mengucapkan terima kasih kepada Kepala Bidang Program Penelitian Dan Pengembangan BAPPEDA Lombok Timur.

\section{Daftar Pustaka}

1. Humantech. 2006. Applied Ergonomics Training Manual. Australia : Barkeley Vale.

2. Depkes, RI. 2009. Profil Kesehatan Di Indonesia Tahun 2008. Jakarta : Pusat Data Dan Informasi Kementerian Kesehatan RI.

3. Tarwaka. 2011. Ergonomi Industri Dasar-Dasar Pengetahuan Ergonomi dan Aplikasi di Tempat Kerja. Solo: Harapan Press.

4. Kemenkes, RI. 2013. Riset Kesehatan Dasar (RISKESDAS). Jakarta : Balitbang Kementerian Kesehatan RI.

5. Riyadina, W., Suharyanto, FX., Dan Tana, L. 2008. Keluhan Nyeri Muskuloskeletal pada Pekerja Industri Di Kawasan Industri Pulo Gadung Jakarta. Majalah Kedokteran Indonesia. Vol. 58, Hal. 1, No. 9.

6. Suryabrata, S. 2012. Metodologi Penelitian. Jakarta: PT. Raja Grafind Persada.

7. Handoko, R. 2013. Statistik Kesehatan Dengan Aplikasi SPSS dalam Prosedur Penelitian. Jakarta: CV. Rihama-Rohima Press.

8. Bridger, R.S. 2003. Introductions to Ergonomics, 2ndEdition. London: Taylor\&Francis Inc.

9. Mutiah, A., Setyaningsih, Y., dan Jayanti, S. 2013. Analisis Tingkat Risiko Musculoskeletal Disorders (MSDs) Dengan The Brief ${ }^{T M}$ Survey dan Karakteristik Individu Terhadap Keluhan MSDs Pembuat Wajan Di Desa Cepogo Boyolali. Jurnal Kesehatan Masyarakat. Fakultas Kesehatan Masyarakat Universitas Diponegoro: Vol. 2, No. 2. http://ejournals1.undip.ac.id/index.php/jkm.

10. Santosa, A., dan Ariska, DK. 2018. Faktor-Faktor Yang Berhubungan Dengan Kejadian Muskuloskeletal Disorders Pada Pekerja Batik Di Kecamatan Sokaraja Banyumas. Jurnal IlmuIlmu Kesehatan Vol. 16, No. 1.Universitas Muhammadiyah Purwokerto.

11. Rahman, A. 2017. Analisis Postur Kerja Dan Faktor Yang Berhubungan Dengan Keluhan Muskuloskeletal Disorders (MSDs) Pada Pekerja Beton Sektor Informal Di Kelurahan Semata 
Kecamatan Somba Opu Kabupaten Gowa Tahun 2017. Skripsi. Makassar: Program Studi Kesehatan Masyarakat Universitas Islam Negeri Alauddin Makassar.

12. Sari, E.N., Handayani, L., dan Saufi, A. 2017. Hubungan Antara Umur dan Masa Kerja dengan Keluhan Muskuloskeletal Disorders (MSDs) pada Pekerja Laundry. Jurnal Kedokteran dan Kesehatan. Fakultas Kesehatan Masyarakat Universitas Ahmad Dahlan Yogyakarta. Vol. 13, No. 2.

13. Rahayu, A.W. 2012. Faktor-Faktor Yang Berhubungan Dengan Keluhan Muskuloskeletal Disorders Pada Pekerja Industri Pemecah Batu Di Kecamatan Karangnongko Kabupaten Klaten. Tesis. Semarang : Universitas Diponegoro.

14. Krisdianto, A., Dewi, P.S.R., dan Ismi, H. 2015. Hubungan Faktor Individu dan Faktor Pekerjaan dengan Keluhan Muskuloskeletal Akibat Kerja (Studi pada Nelayan di Desa Puger Wetan Kecamatan Puger Kabupaten Jember). Artikel Ilmiah Kesehatan Masyarakat. Universitas Jember.

15. Muspika, M. 2017. Basis Otoritas Dalam Praktik Pengobatan Akar Paninggil [Studi Deskriptif tentang Sistem Kepercayaan dan Tindakan Sosial dalam Proses Pemilihan Pengobatan Tradisional di Surabaya]. Skripsi. Surabaya: Program Studi Sosiologi Universitas Airlangga.

16. Zegaria, M.A. 2006. Osteoarthritisin Seniors, Key Elements in Diseases Management. US Pharmacist.

17. Randang, M.J., Kawalu, P.A.T., Dan Sumampouw, O.J. 2017. Hubungan Antara Umur, Masa Kerja, Dan Lama Kerja Dengan Keluhan Muskuloskeletal Pada Nelayan Di Desa Talikuran Kecamatan Remboken Kabupaten Minahasa. Jurnal Media Kesehatan. Vol. 9, Hal. 3, No. 1-8. 